\title{
USAHA GURU BIMBINGAN DAN KONSELING MEMPERBAIKI CARA BELAJAR MELALUI ANALISIS PRILAKU BELAJAR SISWA DI SMP PGRI 9 PALEMBANG
}

\author{
Andrean Gumara ${ }^{1}$, Endang Surtiyoni ${ }^{2}$ \\ Universitas PGRI Palembang ${ }^{1}$ \\ Email: andrean.gumara@gmail.com \\ Universits PGRI Palembang ${ }^{3}$ \\ Email: endangsurtiyoni@gmail.com
}

\begin{abstract}
ABSTRAK
Tujuan dari penelitian ini adalah untuk mengetahui bagaimana bentuk keberhasilan guru bimbingan dan konseling dalam memperbaiki cara belajar siswa dan menganalisi prilaku belajar siswa di SMP PGRI 9 Palembang, untuk mengatasi permasalahan ini maka guru bimbingan dan konseling memberikan layanan bimbingan belajar dengan teknik diskusi untuk membantu siswa mengatasi permasalahan yang ada disekolahan. Metode yang dilakukan dalam penelitian ini adalah penelitian deskriptif kualitatif. Dimana peneliti melakukan informasi atau data yang berkaitan dengan masalah yang diteliti kemudian peneliti menarik kesimpulan informasi dari data yang diteliti. Metode deskriptif dianggap sesuai dengan peneliti ini, karena peneliti menganalisis prilaku belajar siswa di SMP PGRI 9 Palembang.
\end{abstract}

Kata kunci : Layanan Bimbingan Belajar, Cara Belajar Siswa

\section{THE GUIDANCE DDAN COUNSELING TEACHER'S EFFORTS IMPROVE HOW TO LEARN THROUGH STUDENT LEARNING BEHAVIOR ANALSIST IN SENIOR HIGH SCHOOL PGRI 9 PALEMBANG}

\begin{abstract}
The purpose of this research is to find out how the success of guidance and counseling teachers in improving student learning and analyzing student learning behavior at SMP PGRI 9 Palembang, to overcome this problem the guidance and counseling teachers provide tutoring services with discussion techniques to help students overcome problems that exist in school. The method used in this research is descriptive qualitative research. Where the researcher conducts information or data relating to the problem under study then the researcher draws conclusions from the information studied. The descriptive method is considered in accordance with this researcher, because the researcher analyzes the student learning behavior at SMP PGRI 9 Palembang.
\end{abstract}

Keywords: Tutoring Service, Student Learning Method 


\section{PENDAHULUAN}

Kualitas lulusan pendidikan merupakan tanggung jawab kolektif semua pihak yang terlibat dalam pendidikan, lebih-lebih lembaga penyelenggara tenaga kependidikan. Mutu pendidikan dipermasalahkan jika hasil pendidikan belum mencapai taraf kualitas yang diharapkan. Penetapan mutu pendidikan dilakukan oleh lembaga penyelenggaraan tenaga kependidikan. Mutu pendidikan selanjutnya dijadikan sebagai acuan dalam menyatakan kualitas pendidikan yang diinginkan. Oleh karenanya, hasil belajar yang bermutu hanya mungkin dicapai melalui proses belajar yang bermutu pula. Jika proses belajar tidak optimal, maka sangat sulit diharapkan terjadinya hasil belajar yang bermutu. Jika kenyataannya belajar tidak optimal tetapi menghasilkan skor ujian yang maksimal, maka bisa dipastikan hasil belajar tersebut adalah semu. Ini mengindikasikan bahwa masalah pendidikan lebih terletak pada proses pendidikan, khususnya proses belajar mengajar. (Dikutip dari Jurnal yang berjudul "Pengaruh Bimbingan Belajar Dalam Meningkatkan Prestasi Belajar Peserta Didik Kelas VIII Mts Negeri Godean, Sleman, YOGYAKARTA”, Tahun 2012)

Di samping itu, masalah pendidikan dipengaruhi oleh peserta didik, tenaga kependidikan, kurikulum, sarana dan prasarana, bahkan masyarakat sekitar sekalipun. Seberapa besar kontribusi yang diberikan oleh komponen-komponen tersebut sangat tergantung pada seberapa besar dukungan yang diberikan oleh komponen belajar itu. Misalnya, sekolah melakukan bimbingan belajar, tetapi tidak didukung oleh sarana dan prasarana yang mendukung dalam kegiatan tersebut, maka kegiatan bimbingan belajar tidak berjalan secara maksimal.

\section{LANDASAN TEORI}

Berdasarkan penelitian oleh Andayani dkk ( 2014: 2) cukup banyak siswa yang menunjukkan hasil belajar rendah di bawah rata - rata kelas dalam beberapa mata pelajaran, salah satunya mata pelajaran Fisika. Menurut keterangan dari guru bidang studi fisika nilai rata - rata yang ditetapkan oleh sekolah atau nilai KKM adalah 76. Dari 21 siswa dalam satu kelas, ada 8 orang yang menunjukkan hasil 
belajar rendah, siswa tersebut memperoleh nilai kurang dari KKM yaitu 76 ( daftar nilai fisika tahun 2013/2014) .

\section{METODE PENELITIAN}

Metode yang dilakukan dalam penelitian ini adalah penelitian deskriptif kualitaitif. Dimana peneliti melakukan informasi atau data yang berkaitan dengan masalah yang diteliti kemudian peneliti menarik kesimpulan informasi dari data yang diteliti. Metode deskriptif dianggap sesuai dengan peneliti ini, karena peneliti ingin memperbaiki cara belajar siswa dengan mengunakan layanan bimbingan belajar di SMP PGRI 9 Palembang.

Menurut Sugiyono (2016:2) metode penelitian merupakan cara ilimiah untuk mendapatkan data dengan tujuan dan keguruan tertentu.

Sedangkan menurut Nazir dalam kutipan jurnal Ghozali, (2016) pengertian "Metode deskriptif adalah suatu metode dalam meneliti status kelompok manusia, suatu objek, suatu set kondisi, suatu sistem pemikiran, ataupun suatu kelas peristiwa pada masa sekarang”.

Dari definisi di atas dapat disimpulkan bahwa penelitian deskriptif kualitatif adalah suatu metode atau cara dalam meneliti status sekelompok manusia, suatu objek dengan membuat deskriptif, gambaran atau lukisan secara sistematis, faktual dan akurat mengenai fakta-fakta atau fenomena yang diselidiki dengan nyata. Untuk menggambarkan secara utuh dan mendalam tentang realitas sosial dan berbagai fenomena yang terjadi dimasyarakat yang menjadi subjek penelitian, maka dalam penelitian ini penting menggunakan deskriptif kualitatif.

\section{PEMBAHASAN}

Perilaku Belajar dapat diartikan sebagai sebuah aktivitas belajar. Sebenarnya konsep dan pengertian belajar itu sangat beragam tergantung dari sudut pandang setiap orang yang mengamatinya. Belajar sendiri diartikan sebagai perubahan yang secara relatif berlangsung lama pada perilaku yang diperoleh kemudian dari pengalaman-pengalaman.

Dalam penelitian yang dilakukan oleh peneliti ada beberapa faktor yang mempengaruhi perilaku belajar siswa SMP PGRI 9 Palembang yaitu: 
1. Siswa merasa bosan dengan apa yang di sampaikan guru karna gaya mengajarnya yang monoton dan siswa menginginkan guru yang mengajar tidak hanya menyampaikan materi saja tetapi juga disertai dengan penyampaian yang kreatif agar siswa merasa tertarik dan semangat belajar.

2. Pengaruh teman yang mengajak teman sebangkunya untuk ngobrol dan ada juga yang mengganggu temannya, bagi siswa yang serius dalam mendengarkan penjelasan yang disampaikan guru sungguh sangat mengganggu dan akhirnya memunculkan reaksi untuk melawan atau menanggap teman lainnya"

3. Kondisi lingkungan kelas yang mempengaruhi prilaku siswa dalam melakukan kegiatan belajar, siswa merasa ketika cuaca panas terik mengakibatkan tubuh mereka lemas dan gerah sehingga tidak semangat dalam belajar.

Dari beberapa faktor yang mempengaruhi perilaku belajar siswa SMP PGRI 9 Palembang, guru BK tidak melakukan tugasnya secara perseorangan, ada upaya yang dilakukan oleh guru BK dalam menganalisis perilaku belajar siswa yaitu melakukan kerja sama dengan wali murid dan guru mata pelajaran, guru BK banyak mendapat informasi dari mereka tentang keadaan siswa di dalam kelas, juga dari data-data yang di berikan wali kelas tentang daftar nilai siswa yang ada di sana. Selalu melakukan kerjasama dan melakukan kontrol rutin terhadap siswa yang mengalami masalah terhadap prilaku belajar harus selalu di lakukan oleh guru BK maupun para guru yang ada di sekolah tersebut agar tercapainya tujuan pendidikan, siswa terus mendapatkan perhatian hingga ia dapat menemukan jalan keluar dari masalah nya secara mandiri dan melakukan layanan layanan konseling seperti konseling individu, konseling kelompok dan lain-lain untuk mengentaskan masalah para siswanya, dan tak hanya sekali melakukan layanan konseling kepada siswanya guru BK disini melakukan layanan secara berkesinambungan dan terus mengontrol siswanya, dengan dibantu oleh pihaksekolah lainnya seperti wali kelas dan juga guru mata pelajaran yang ada.

Namun dengan begitu ada beberpa kendala yang dihadapi guru BK dalam menganalisis perilaku belajar siswa SMP PGRI 9 Palembang yaitu siswa masih 
takut dan canggung dalam mengungkapkan masalahnya yang artinya siswa masih belum mempercai guru BK sepenuhnya, ketidak ahlian guru BK dalam bersosilisasi dan menjadi sahabat bagi siswa juga menjadi kendala dalam mengungkapkan isi hati mereka. Sulitnya menggali informasi dari siswa yang menghambat suatu proses pengentasan suatu masalah, tak hanya itu kurangnya dukungan dari pihak lain dalam mengentaskan masalah belajar siswa mengakibatkan guru BK harus ekstra keras dalam menangani hal tersebut.

Penelitian ini menggunakan teori Hilgard dan Blower dalam buku Teroris of Learning (1975) menyatakan bahwa "belajar berhubungan dengan tingkah laku seseorang terhadap suatu situasi tertentu yang disebabkan oleh pengalamannya yang berulang-ulang dimana perubahan tingkah laku itu tidak dapat dijelaskan atau dasar respons pembawaan.

Dari teori tersebut dapat dikaitan dengan penelitian yang dilakukan oleh peneliti yang berjudul Analisis guru BK terhadap perilaku belajar siswa di sekolah SMP PGRI 9 Palembang, teori yang diambil oleh peneliti berkaitan dengan tingkah laku belajar, yang mana setiap siswa memiliki tingkah laku tertentu dari situasi yang dialami nya.

\section{KESIMPULAN}

Berdasarkan hasil penelitian diatas, penulis menguraikan kesimpulan sebagai berikut:

1. Beberapa faktor yang mempengaruhi prilaku belajar siswa SMP PGRI 9 Palembang yaitu Siswa merasa bosan dengan apa yang di sampaikan guru yang monoton dalam penyampaian materi, pengaruh teman yang mengajak teman sebangkunya untuk ngobrol dan kondisi lingkungan kelas dan cuaca yang panas.

2. Dari beberapa faktor tersebut ada upaya yang dilakukan oleh guru BK dalam menganalisis perilaku belajar siswa SMP PGRI 9 Palembang yaitu melakukan kerjasama dengan guru mata pelajaran lain dan dengan wali murid serta melakukan layanan-layanan konseling seperti konseling individu, konseling kelompok dan lain-lain untuk mengentaskan masalah para siswanya. 
3. Dari upaya tersebut memiliki kendala yang harus dihadapi oleh para guru BK Dalam menganalisis prilaku belajar siswa SMP PGRI 9 Palembang yaitu siswa yang masih takut dan canggung dalam menyampaikan masalah yang dialaminya kepada guru BK, para siswa yang belum sepenuhnya mempercayai guru BK dan ketidakahlian guru BK dalam bersosilisasi dan menjadi sahabat bagi siswa juga menjadi kendala dalam mengungkapkan isi hati mereka. Serta kurangnya dukungan dari pihak lain dalam mengentaskan masalah belajar para siswa.

4. Dalam proses bimbingan konseling, permasalahan yang dihadapi siswa tidak serta merta dipengarushi oleh satu aspek, namun dipengaruhi oleh berbagai aspek baik itu dari internal siswa sendiri maupun dari luar diri siswa.

\section{DAFTAR PUSTAKA}

Andayani, dkk. 2014. Penerapan Layanan Bimbingan Belajar Untuk Meningkatkan Prestasi Belajar Bagi Siswa Yang Mengalami Kesulitan Belajar Siswa Kelas X4 Sma Negeri 1 Sukasada. Info, Vol 2 No 1

Ferdiansyah, M. 2015. Dasar Penelitian Kualitatif . Bogor: Herya Media

Fiah, E. R., \& Purbaya, P. A. (2016). Penerapan Bimbingan Belajar Dalam Meningkatkan Hasil Belajar Peserta Didik Di Smp Negeri 12 Kota Bandar Lampung Tahun Pelajaran 2015/2016. Info ISSN 2089-9955

Irfan, Ahmad. 2016. Hubungan Antara Layanan Bimbingan Belajar Dengan Ke sulitan Belajar Siswa Kelas IX SMP NEGERI 2 TURI TAHUN AJARAN 2015/16.

Tim Penyusun. 2019. Pedoman Penulisan Skripsi. Palembang: FKIP Universitas PGRI Palembang. 